\title{
How Did Banks and Investors Respond to the 2020 Stress Test Results?
}

\author{
By W. Blake Marsh
}

The COVID-19 pandemic heightened investor, regulatory, and supervisory concerns about the U.S. banking system's ability to survive a downturn. Both businesses and consumers pulled back on economic activity at the start of the health crisis, leading firm revenue to decline sharply amid fears of rapidly accelerating job losses, business closures, and lower household incomes. As a result, expectations that businesses and consumers would be unable to continue servicing their debt obligations increased. Investors and bank supervisors began bracing for significant losses at banks, which could threaten the stability of the broader financial system.

Policymakers moved quickly to backstop financial markets while supervisors tried to ensure banks could withstand the anticipated loan losses. In June 2020, the Board of Governors of the Federal Reserve System took steps to preserve capital at large banks by capping dividend payments to shareholders and prohibiting common stock repurchases outright for some time. In doing so, supervisors looked to prevent banks from repeating behaviors observed during the 2007-09 global financial crisis (GFC). During that crisis, banks continued to pay dividends to shareholders while suffering sizable losses. Ultimately, those losses left many banks teetering on the edge of failure, and a federal bailout was required to keep the system afloat.

W. Blake Marsh is a senior economist at the Federal Reserve Bank of Kansas City.

This article is on the bank's website at www.KansasCityFed.org 
How the dividend caps and repurchase restrictions affected banks, however, is an open question with important policy ramifications. If investors sell stocks in response to dividend caps, for example, then falling stock prices will hamper banks' ability to raise new equity funding at a time when it might be needed to offset loan losses.

In this paper, I examine how the announcement of the payout restrictions influenced bank capital levels and stock prices. I find that the restrictions helped build capital levels at large banks but may have indirectly hampered stock price returns. First, I show that surprisingly strong income growth combined with the payout restrictions drove capital to near record levels during this period. Second, I show that the payout restrictions had only a minimal effect on stock prices for most banks. Instead, the threat of increased supervisory stringency appears to have generated more persistent effects on stock prices, particularly for directly affected banks and those near the supervisory threshold. My results suggest that the post-GFC supervisory preference for payouts to be conducted primarily through repurchases, rather than dividends, provided a capital conservation channel that had only modest effects on bank stock returns.

Section I discusses why firms conduct shareholder payouts and reviews previous findings on bank payout policies. Section II reviews how the Federal Reserve limited bank payouts to investors during the pandemic. Section III shows that these restrictions helped boost bank capital, but the perception of increased supervisory stringency likely lowered stock prices.

\section{Why Do Banks Pay Dividends and Repurchase Shares?}

Typically, banks make payouts to investors through either dividends or common stock repurchases. Dividends are regular cash payments banks make to all shareholders of record. Common stock repurchases, on the other hand, are bank purchases of their own stock from investors. Stock repurchases should result in a capital gain for shareholders who do not tender shares in the repurchase, all else equal, because fewer available shares will increase the price of outstanding stocks. Banks typically use earned income to fund both payout types. However, payouts that exceed earned income levels will reduce capital levels. The potential for payouts to negatively affect capital levels is the key reason 
regulators and supervisors pay close attention to payout policies at financial institutions. ${ }^{1}$

In recent years, payouts by the largest U.S. banks have soared to record levels. Chart 1 shows that just prior to the pandemic, global systemically important banks (GSIBs) repurchased more than $\$ 30$ billion in common stock while paying out an additional $\$ 10$ billion in dividends per quarter. In many cases, annual payouts at these banks exceeded earned income levels. At the same time, smaller peer banks that also participate in the Federal Reserve's annual stress tests and Comprehensive Capital Analysis and Review (CCAR) reported steady increases in stock repurchases and some dividend growth as well.

Chart 1 also shows that large U.S. banks have clearly preferred repurchases over dividends since the GFC. Prior to the GFC, dividends and repurchases were of roughly equal volumes at both GSIBs and other CCAR banks. After the recession, however, the volume of these payouts diverged: in 2019, repurchases accounted for about two-thirds of payouts at GSIBs and about one-half of total payouts at all other CCAR banks.

Relative adjustments between dividend and repurchase levels are not unusual. Banks are generally more reluctant to cut dividends than repurchases: even in normal times, stock prices generally fall in response to dividend cuts (Bessler and Nohel 1996). As a result, many banks did not cut dividends during the GFC even when they experienced sharp income reductions (Hirtle 2014; Floyd, Li, and Skinner 2015). Instead, they dramatically reduced the size of their repurchase programs. Cuts to repurchase programs are not thought to elicit the same backlash from investors, in part because they are so variable in size and frequency ( $\mathrm{Li}$ ang 2020). Thus, repurchase reductions may not spur large declines in stock prices, allowing banks to raise funds through equity issuance if needed while still conserving income during times of stress. Following the GFC, supervisors acknowledged these differences by implicitly capping dividend payments at 30 percent of total payouts, expressing a clear preference for repurchase programs over larger dividends (Kohn and Liang 2019).

Despite notions of a limited stock market reaction to repurchase cuts, shareholders may still be attuned to changes in both dividends and repurchases because they signal information about a bank's future 


\section{Chart 1}

Large Bank Payout Levels, 1999-2021

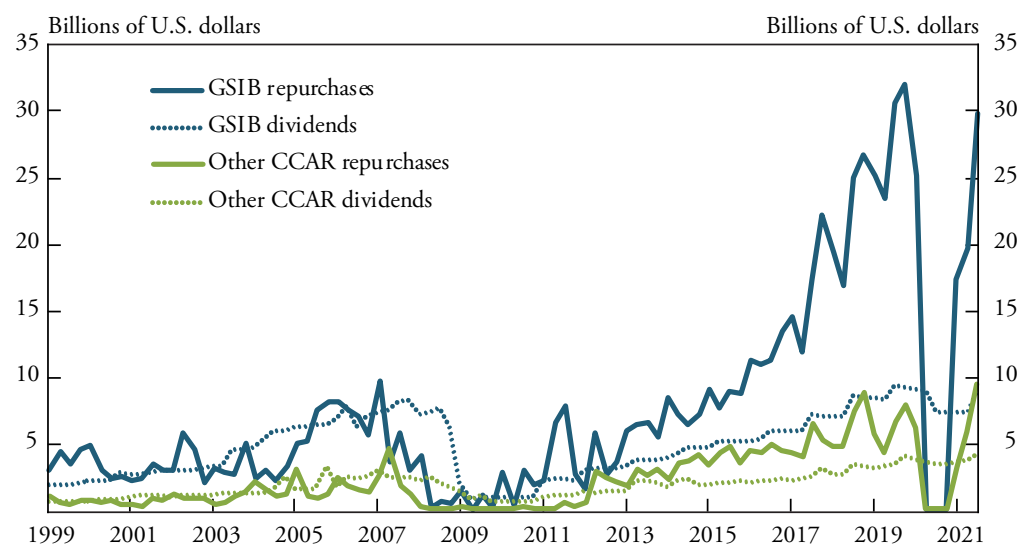

Source: Board of Governors of the Federal Reserve System.

performance (Bhattacharya 1979). Bessler and Nohel (1996) argue that shareholders react negatively to dividend cuts because they convey negative information about the firm's prospects. Similarly, Vermaelen (1981, 1984) and Hirtle (2004) find that increases in the size of repurchase programs signal future profitability.

Shareholders might also care about changes to both dividends and repurchases to the extent that these payouts help discipline banks and prevent risk-taking. Firms with an excess of free cash flow might be tempted to invest poorly or spend frivolously (Jensen and Meckling 1976; Jensen 1986). Payouts provide one way to reduce the stock of excess cash and discipline bank management to invest more prudently. Repurchases are particularly important for helping banks achieve optimal capital targets (Laderman 1995; Hirtle 1998). Otherwise, banks that hold very high levels of excess capital may be inclined to risk shareholder value by "reaching for yield" to increase their return on equity.

However, lower capital holdings may not be ideal, particularly in times of stress. Banks with lower capital holdings can endure fewer loan losses before they fail. Moreover, large banks that pose systemic risk to the financial system often do not internalize the social costs of their failures. In these cases, regulatory tools such as minimum capital standards are needed to achieve higher capital levels than banks or their investors might otherwise prefer. 


\section{What Steps Did the Federal Reserve Take in 2020 to Limit Payouts?}

Capital requirements are the primary tool for limiting bank payouts. All banks are required to hold some level of minimum capital depending on the size and riskiness of their loan portfolios. ${ }^{2}$ Capital requirements are higher for the largest banks due to their systemic importance and the social costs that would be incurred from a large bank failure. Since the GFC, the Federal Reserve has also conducted annual supervisory stress tests (formally, the CCAR) of the largest and most systemically important banking organizations. These stress tests project capital losses at banks under a series of hypothetical macroeconomic downturns and require banks to hold enough capital to absorb these

projected losses. Banks required to raise additional capital following the stress tests are subject to payout limitations.

Federal Reserve bank supervisors conducted the 2020 stress tests of large banks when the pandemic-related downturn was already underway. All banks performed well in the standard stress tests; however, supervisors also conducted an additional "sensitivity analysis" to assess banking system vulnerabilities associated with the pandemic downturn and avoid the need to recapitalize banks in the future. In the sensitivity analyses, supervisors found that under some scenarios, projected capital buffers would fall at or below minimum levels for many banks. This result, combined with a great deal of uncertainty around the projections, compelled supervisors to limit bank capital distributions to shareholders for a time as the economy recovered. These restrictions were implemented in two parts (Board of Governors of the Federal Reserve System 2020). First, supervisors suspended bank share repurchase programs indefinitely. Second, supervisors instituted dividend caps that stipulated dividends could not rise above pre-pandemic levels and could not exceed the average of a bank's prior four quarters of net income. Dividends could be paid above these limits only with approval by the Board of Governors.

These restrictions were likely surprising to investors. In March 2020, the Board of Governors adopted new rules that based large bank capital requirements in part on stress test results. These rules required banks participating in the CCAR exercise to hold a "stress capital buffer" equal to projected capital losses under a severely adverse supervisory 
stress scenario plus four quarters of planned common stock dividends. In addition, the rules stipulated that the stress capital buffer could not be lower than 2.5 percent of a bank's total risk-weighted assets. ${ }^{3}$ Banks holding less than the minimum stress capital buffer would be subject to restrictions on dividends and share repurchases. These rules provided a mechanical way to incorporate the stress test results into required capital levels and removed both the soft cap on dividend payments as well as several qualitative requirements that needed supervisory approval. Given these changes to the supervisory stress test framework, judgmental interventions such as the "sensitivity assessment" and the imposition of broad payout restrictions should have been limited.

How bank shareholders responded to the payout restrictions announced during the 2020 stress tests is an open question. On the one hand, the restrictions might have conveyed bad news for investors along several dimensions. For example, investors may have interpreted an increase in required capital buffers as suggesting that bank losses would be larger or more imminent than expected. In addition, investors may have worried that increased capital buffers would incentivize banks to take on riskier but higher earning investments to justify the higher capital holdings-behavior that could put investor money at risk as bank failure probabilities rise. Finally, investors might have interpreted these restrictions as signaling more stringent supervisory oversight, which might limit future risk-taking and profitability. All these considerations would push bank stock prices down.

On the other hand, investors may not have been concerned about these restrictions given that they were announced at a time of elevated uncertainty about future loan losses. Higher capital levels reduce the probability of bank failures (and, subsequently, investor losses). In addition, many large banks had already announced the cessation of repurchase programs before the new restrictions took effect, and investors had likely already priced in those announcements. Moreover, although the restrictions capped dividend growth, they allowed banks to continue making their current dividend payments so long as income levels held steady. Thus, the restrictions may have had little effect on bank stock prices. 


\section{How Did the 2020 Payout Restrictions Affect Banks?}

I evaluate the effect of the 2020 payout restrictions on banks in two dimensions. First, I estimate how much affected bank capital buffers increased given income levels earned in 2020 and the prevailing payout rates prior to the pandemic. Second, I estimate how bank stocks performed following the stress test announcement to gauge the response of investors to the restrictions.

Overall, payout restrictions materially increased bank capital levels. Following the payout restrictions, banks cut repurchases to zero and held dividends steady (see Chart 1). ${ }^{4}$ At the same time, banks' reported income levels outperformed expectations. Chart 2 shows that income earned at large banks outperformed investor expectations throughout 2020. At the end of 2019, just prior to the start of the pandemic in the United States, investors expected earnings per share of more than $\$ 5$ at GSIBs over the next four quarters. Earnings per share were expected to top $\$ 4$ at all other CCAR banks and about $\$ 2.50$ at publicly traded banks not subject to stress testing. In March 2020, expected bank earnings declined by more than half for all CCAR banks and more than 40 percent for non-stress-tested banks. However, actual earnings growth was surprisingly strong during the pandemic. Although cumulative reported earnings were below pre-pandemic expectations, realized bank income was higher than expected at the onset of the pandemic, particularly at the largest banks. Despite limited loan growth throughout the pandemic, large banks saw robust trading and investment banking activity that supported net income (Sengupta and Byrdak 2021). At the same time, expected loan losses never materialized, likely due to extraordinary policy support from fiscal and monetary agents. As a result, realized income outpaced pandemic expectations.

The combined effect of earned income and restricted payouts increased capital levels during 2020. On net, common equity Tier 1 capital ratios rose 57 basis points to 12.6 percent for GSIBs and 100 basis points to 11.1 percent for all other CCAR banks between year-end 2019 and year-end 2020. Chart 3 shows the contribution of the payout restrictions to relative capital levels at CCAR banks compared with capital levels that would have prevailed if banks had paid out income at 2019 payout ratios. For GSIBs, lower relative payouts added a full 60 basis points to capital ratios, accounting for the bulk of the net increase 


\section{Chart 2}

\section{Projected and Realized Bank Earnings}

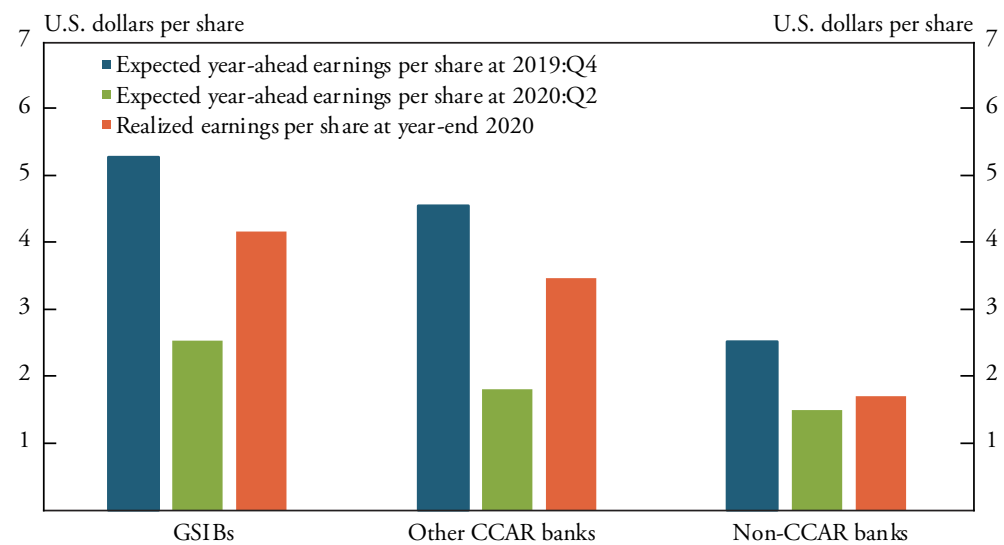

Notes: Blue and green bars show expected earnings per share one year ahead for 2019:Q4 and 2020:Q2, weighted by shares outstanding at the end of each respective quarter. Orange bars show aggregate earnings per share at the end of 2020 .

Sources: Refinitiv Eikon/Institutional Brokers' Estimate System (IBES) and Board of Governors of the Federal Reserve System.

\section{Chart 3}

\section{Effect of Payout Restrictions on Bank Capital Ratios}

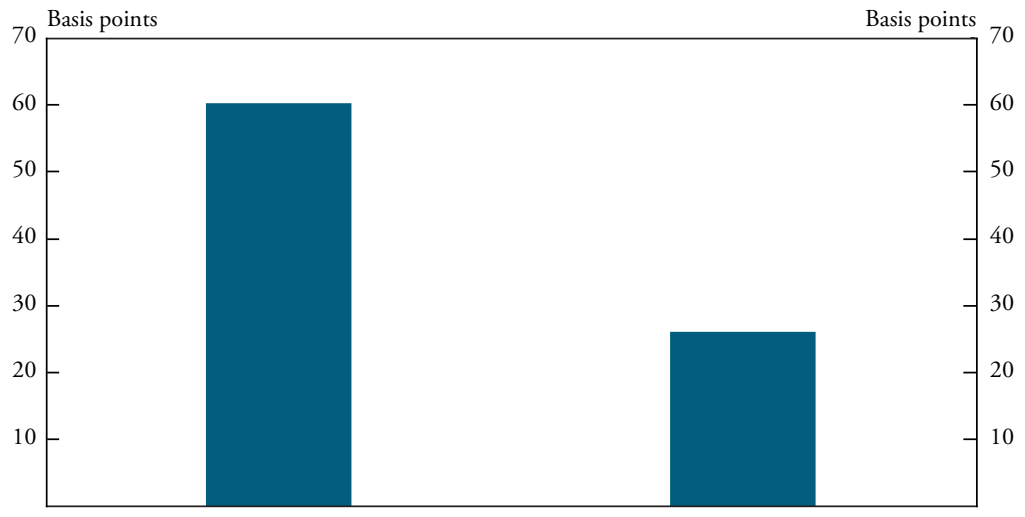

Capital ratios at GSIBs

Capital ratios at other CCAR banks

Note: Effects of payout restrictions on capital ratios are calculated as aggregate net income available to shareholders earned in 2020 times the change in the aggregate payout rate between 2020 and 2019 expressed as a fraction of risk-weighted assets at year-end 2020.

Sources: Board of Governors of the Federal Reserve System and author's calculations. 
in the aggregate common equity Tier 1 capital ratio at the end of 2020 . For all other CCAR banks affected by the payout restrictions, the aggregate common equity capital ratio was more than 25 basis points higher than it would have been at 2019 payout levels.

These higher capital levels made banks stronger and more resilient to future economic downturns. However, they may have had a negative effect on stock prices to the extent that shareholders reacted unfavorably to these restrictions. To assess shareholder reactions, I first use a predictive model to forecast individual stock returns based on market-wide movements in a broad stock index. I then compare the cumulative returns on stocks to these predicted returns over various windows (model details and additional analysis are available in Marsh 2022). I refer to the difference between actual and predicted cumulative returns as "excess returns"that is, the additional return realized over the model's prediction.

Chart 4 shows the excess returns over various windows for banks subject and not subject to the Federal Reserve's stress test. Stress-tested banks had lower-than-expected returns immediately following the announcement of the CCAR results and the payout restrictions. However, banks not subject to stress testing, and therefore not subject to payout restrictions, had higher-than-expected realized returns. Over longer windows, I find that the result for stress-tested banks is persistently negative: realized returns were lower than expected at CCAR banks up to a full quarter after the announcement. Banks not subject to stress testing had mixed responses. Up to one month after the payout restriction announcement, non-stress-tested banks also had lower realized returns than predicted. However, unaffected banks outperformed stress-tested banks over longer windows, making the negative response temporary. After one quarter, banks not subject to stress testing had higher-than-predicted returns.

The predictive model alone cannot assess why investors reacted to the announcements the way they did. To understand investors' reactions, I reexamine excess returns conditional on pre-pandemic bank characteristics, expected earnings, and default probabilities. These results highlight which features investors regarded as important when pricing bank stocks. For example, investors may have rewarded banks that paid larger dividends because they would have been less affected by the payout restrictions. Similarly, investors may have punished stock 


\section{Chart 4}

Bank Stock Price Reactions to Payout Restriction Announcements

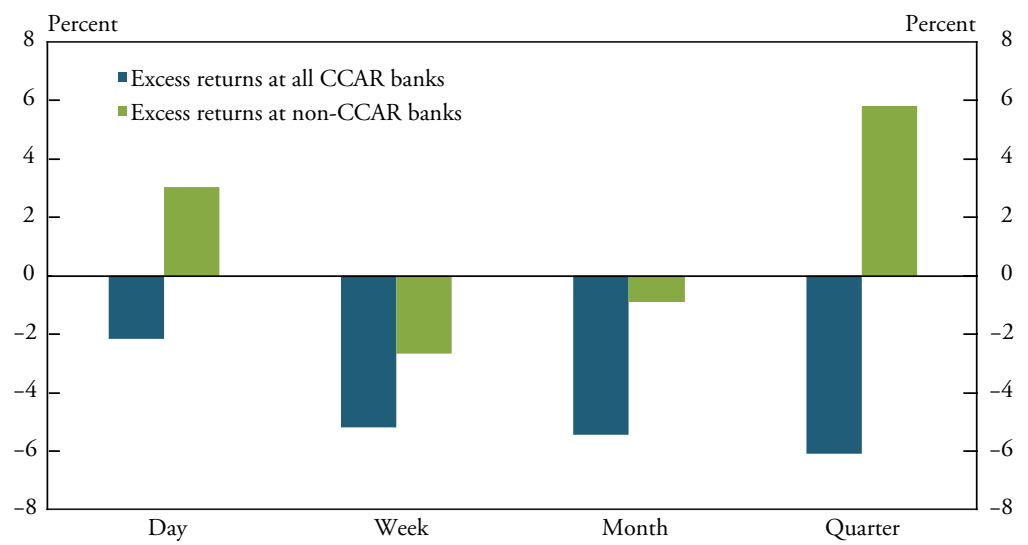

Source: Author's calculations.

prices of banks with larger excess capital holdings because these stocks would continue to grow with income and incentivize banks to take on additional risk.

Table 1 reproduces the results of a regression of the standardized excess return on measures of bank size, profitability, capitalization, business model, and expected earnings from Marsh (2022). Column (1) shows that in a simple model, investors regarded bank size (measured by the natural log of assets) and the dividend rate as the most important characteristics when pricing stocks following the payout restriction announcement. Bank size is highly correlated with the imposition of the restrictions because only banks over $\$ 100$ billion are subject to stress testing. Overall, a 1 percent increase in asset size is associated with about a 33 basis point reduction in excess returns over the two-day window. In addition, banks that paid larger dividends, and could therefore pay out larger shares of income via dividends, experienced larger excess returns than those that paid smaller dividends. An increase of dividends relative to capital of 1 percent is associated with about a 4 basis point increase in two-day excess returns. Larger pre-pandemic dividends were advantageous because the restrictions limited future dividend growth but did not curtail existing dividends unless income declined precipitously. The pre-pandemic size of the repurchase program did not affect 


\section{Table 1}

Cross-Section Analysis of Cumulative Abnormal Returns

\begin{tabular}{|c|c|c|c|c|c|}
\hline \multirow[b]{2}{*}{ Independent variables } & \multicolumn{5}{|c|}{ Dependent variable } \\
\hline & (1) & (2) & (3) & (4) & (5) \\
\hline $\ln$ (Assets) & $\begin{array}{c}-33.42^{* * *} \\
(2.79)\end{array}$ & $\begin{array}{c}-32.14^{* * *} \\
(3.44)\end{array}$ & $\begin{array}{c}-32.79^{* *} \\
(3.18)\end{array}$ & $\begin{array}{c}-32.63^{* * *} \\
(3.53)\end{array}$ & $\begin{array}{c}-33.15^{* * *} \\
(3.53)\end{array}$ \\
\hline Dividend rate & $\begin{array}{l}3.85^{* *} \\
(1.91)\end{array}$ & $\begin{array}{c}3.71^{*} \\
(1.96)\end{array}$ & $\begin{array}{c}1.84 \\
(1.98)\end{array}$ & $\begin{array}{c}1.81 \\
(1.96)\end{array}$ & $\begin{array}{c}2.38 \\
(1.92)\end{array}$ \\
\hline Repurchase rate & $\begin{array}{l}-1.00 \\
(0.79)\end{array}$ & $\begin{array}{c}-0.79 \\
(0.82)\end{array}$ & $\begin{array}{l}-0.21 \\
(0.79)\end{array}$ & $\begin{array}{l}-0.19 \\
(0.80)\end{array}$ & $\begin{array}{l}-0.36 \\
(0.83)\end{array}$ \\
\hline Tier 1 ratio & $\begin{array}{c}1.21 \\
(1.57)\end{array}$ & $\begin{array}{c}1.83 \\
(1.85)\end{array}$ & $\begin{array}{c}2.15 \\
(1.64)\end{array}$ & $\begin{array}{c}2.14 \\
(1.64)\end{array}$ & $\begin{array}{c}2.32 \\
(1.58)\end{array}$ \\
\hline Non-interest income share & & $\begin{array}{l}-0.37 \\
(0.26)\end{array}$ & $\begin{array}{l}-0.11 \\
(0.28)\end{array}$ & $\begin{array}{l}-0.11 \\
(0.28)\end{array}$ & $\begin{array}{l}-0.08 \\
(0.28)\end{array}$ \\
\hline Loans to assets & & $\begin{array}{c}-0.12 \\
(0.29)\end{array}$ & $\begin{array}{c}0.12 \\
(0.30)\end{array}$ & $\begin{array}{c}0.11 \\
(0.28)\end{array}$ & $\begin{array}{c}0.08 \\
(0.29)\end{array}$ \\
\hline Deposit concentration & & & $\begin{array}{c}-27.43^{* *} \\
(11.09)\end{array}$ & $\begin{array}{l}-27.19^{* *} \\
(10.99)\end{array}$ & $\begin{array}{l}-30.39^{* * *} \\
(11.17)\end{array}$ \\
\hline Repricing/maturity gap & & & $\begin{array}{c}3.52^{*} \\
(1.84)\end{array}$ & $\begin{array}{c}3.45^{*} \\
(1.87)\end{array}$ & $\begin{array}{l}3.64^{* *} \\
(1.84)\end{array}$ \\
\hline 2020:Q1 earnings forecast & & & & $\begin{array}{c}-0.27 \\
(1.59)\end{array}$ & $\begin{array}{c}-0.01 \\
(1.58)\end{array}$ \\
\hline Default distance & & & & & $\begin{array}{l}-6.70 \\
(4.43)\end{array}$ \\
\hline Constant & $\begin{array}{l}569.64^{* * *} \\
(47.21)\end{array}$ & $\begin{array}{l}557.88^{* * *} \\
(47.31)\end{array}$ & $\begin{array}{l}535.38^{* * *} \\
(65.17)\end{array}$ & $\begin{array}{l}534.71^{* * *} \\
(67.13)\end{array}$ & $\begin{array}{l}550.41^{* * *} \\
(67.41)\end{array}$ \\
\hline Observations & 173 & 173 & 172 & 172 & 172 \\
\hline Adjusted & 0.65 & 0.65 & 0.67 & 0.67 & 0.67 \\
\hline
\end{tabular}

* Significant at the 10 percent level

** Significant at the 5 percent level

*** Significant at the 1 percent level

Notes: Dependent variable is the standardized cumulative abnormal return from a two-day window that includes the trading day following the CCAR announcement and the next day. Balance sheet and income measures are as of 2019:Q4. Earnings forecast is the median year-ahead earnings forecast from IBES as of March 31, 2020. Robust standard errors are in parentheses.

Source: Marsh (2022).

excess returns across any specification, likely because banks had already cut these repurchase programs prior to the stress test announcements.

Several factors could have driven both the dividend and bank size results, however. For example, investors may have interpreted a lower dividend rate as a sign that earnings were under pressure and rewarded banks that continued paying higher dividends. Alternatively, investors may have rewarded banks that pay higher dividends simply because those banks have greater earnings possibilities either due to business 
model differences or geographic diversity. The results for bank size might reflect the effect of increased stringency at larger banks, a more downbeat forecast of future performance for larger banks compared with smaller banks, or the perception that regulators were less willing to step in and assist these banks should loan losses materialize. I investigate each of these possibilities in columns (2) through (5).

Column (2) controls for differences in a bank's business model. Large, publicly traded banks conduct a wide range of lending, brokerage, and trading services for clients, all of which have a different earnings profile. As a result, banks with more numerous income sources may be able to generate higher income throughout the business cycle, enabling consistently higher dividend payments. I control for these business model differences by adding the share of loans outstanding to total assets and the amount of net revenue a bank earns from nonlending activities. The results show that even after controlling for these business model differences, dividends and bank size still significantly explain the excess returns around the stress test announcement.

Column (3) considers additional earnings sources. Banks with a broader geographic footprint might have more consistent investment opportunities, allowing them to pay larger dividends. Similarly, banks whose assets reprice less frequently or mature later will be less sensitive to the declining interest rates observed during the pandemic, again allowing them to pay larger dividends. I control for these factors by measuring each bank's deposit concentration at the county level and the average time between the maturity of a bank's assets and of its liabilities. ${ }^{5}$ After controlling for investment opportunities and interest rate sensitivity, the dividend result from Table 1 is smaller and no longer statistically significant. This suggests that higher dividends were simply a proxy for greater earnings and investment opportunities and are not related to the payout restriction parameters.

Next, column (4) controls for the possibility that larger banks simply had a larger decline in forecast earnings between the first and second quarters of 2020 (as shown in Chart 2). This difference could explain why large banks had larger declines in stock returns. However, after controlling for the level of expected earnings in 2020:Q1, I find that the coefficient on bank size remains similarly sized and statistically significant.

Finally, column (5) considers whether investors interpreted the greater supervisory stringency as a sign that the probability of large 


\section{Chart 5}

Bank Size and Cumulative Abnormal Returns after 2020 Stress Test Results

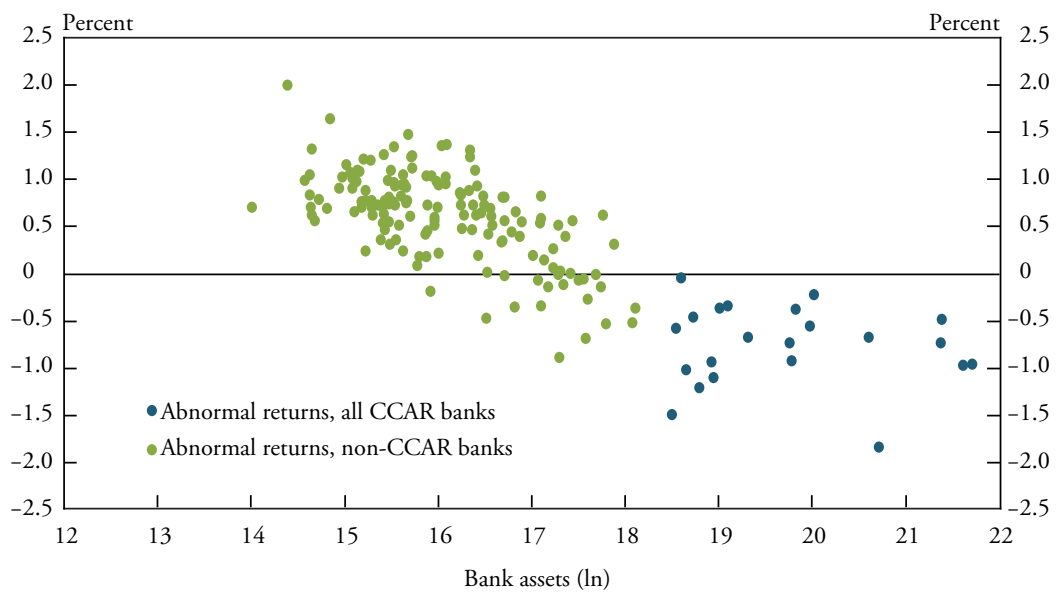

Sources: The Center for Research in Security Prices (Wharton Research Data Services), Board of Governors of the Federal Reserve System, and authors' calculations. ${ }^{6}$

bank failures had increased or that the possibility of bank bailouts in the event of excessive losses was lower. I control for this possibility by including each bank's distance to default and find essentially no change in the bank size coefficient.

The results in Table 1 demonstrate that bank stock prices appear to be relatively insensitive to the payout restrictions that were announced as part of the 2020 stress test results. The parameters most affected by the restrictions, namely the dividend and repurchase rate, do not significantly explain stock returns during very short trading windows following the announcement of payout restrictions. Instead, stock prices performed more poorly following the announcement as bank size increased. Indeed, Chart 5 shows a strong negative relationship between bank size and abnormal returns in the days following the announcement of the stress test results and restrictions. After ruling out several possibilities that might explain this relationship, including increased failure probabilities and lower expected earnings, I conclude that the stress test results suggested an increase in supervisory stringency that was likely to be more severe for larger banks. 


\section{Conclusion}

The COVID-19 pandemic increased the possibility that large, systemically important banks would suffer substantial losses that threatened their survival. In response, bank supervisors conducted additional stress-testing exercises and imposed restrictions on dividend payments and stock repurchases to preserve bank capital.

I investigate how supervisory actions affected bank capital and how investors responded to the actions. I find that supervisory actions were effective at raising capital levels because they limited the share of income paid out to investors and occurred at a time when bank income was stronger than expected. Overall, the restrictions were effective at raising capital while preserving banks' ability to continue to pay dividends-a key post-crisis supervisory goal.

However, I also find that the imposition of these restrictions implied to investors that large banks would face greater supervisory stringency in the future. As a result, stock price returns were lower than expected among stress-tested banks. Even among unaffected banks, abnormal stock returns declined as bank size increased, suggesting to investors that banks closest to the supervisory threshold were also likely to face increased supervisory stringency.

Nonetheless, my results provide a justification for the use of judgmental assessments by supervisors, particularly during times of crisis. Although the results indicate that increased supervisory stringency was costly to banks during this time, the restrictions were successful at materially raising bank capital levels. Increased supervisory stringency was likely warranted given the very high levels of uncertainty that prevailed at the time. The stock price results illustrate the importance of robust and flexible supervisory regimes that can be used to counter market pressure on banks to reduce capital levels. 


\section{Endnotes}

${ }^{1}$ Allen and Michaely (2003) provide an extensive review of research on payout policy, including the choice of payout tool, measurement issues, and theory around the importance of payouts to shareholders and management.

${ }^{2}$ Individual capital requirements are too numerous to explore here. However, the key capital requirements are the leverage ratio, which determines capital based on bank size without regard to the riskiness of the portfolio, and risk-based capital requirements, which are determined based on the potential for the loan portfolio to generate losses during stress.

${ }^{3}$ Risk-weighted assets are the total amount of assets held by a bank adjusted for their riskiness. Under risk-based capital regimes, less risky assets such as Treasury securities have lower capital requirements than riskier assets such as business loans. Minimum risk-based capital requirements are expressed as a percentage of these risk-weighted assets.

${ }^{4}$ Only one CCAR-participating bank was required to cut dividends based on income levels under the payout restrictions.

${ }^{5}$ Deposit concentration is based on a Herfindahl-Hirschman Index calculated from deposits booked at local branches by county. Branch-level data are reported on the Summary of Deposits.

'I used Wharton Research Data Services (WRDS) in preparing the chart. This service and the data available thereon constitute valuable intellectual property and trade secrets of WRDS and/or its third-party suppliers. 


\section{References}

Allen, Franklin, and Roni Michaely. 2003. "Payout Policy," in George M. Constantinides, Milton Harris, and René M. Stulz, eds., Handbook of the Economics of Finance. Amsterdam: Elsevier.

Bessler, Wolfgang, and Tom Nohel. 1996. "The Stock Market Reaction to Dividend Cuts and Omissions by Commercial Banks.” Journal of Banking \& Finance, vol. 20, no. 9, pp. 1485-1508. Available at https://doi.org/10.1016/ S0378-4266(96)00004-0

Bhattacharya, Sudipto. 1979. "Imperfect Information, Dividend Policy, and the 'Bird in the Hand' Fallacy." Bell Journal of Economics, vol. 10, no. 1, pp. 259-270. Available at https://doi.org/10.2307/3003330

Board of Governors of the Federal Reserve System. 2020. Assessment of Bank Capital during the Recent Coronavirus Event. June. Washington, DC: Board of Governors of the Federal Reserve System.

Floyd, Eric, Nan Li, and Douglas J. Skinner. 2015. "Payout Policy through the Financial Crisis: The Growth of Repurchases and the Resilience of Dividends." Journal of Financial Economics, vol. 118, no. 2, pp. 299-316. Available at https://doi.org/10.1016/j.jfineco.2015.08.002

Hirtle, Beverly. 2014. "Bank Holding Company Dividends and Repurchases During the Financial Crisis." Federal Reserve Bank of New York, Staff Report no. 666, March. Available at https://doi.org/10.2139/ssrn.2423384

- 2004. "Stock Repurchases and Bank Holding Company Performance." Journal of Financial Intermediation, vol. 13, no. 1, pp. 28-57. Available at https://doi.org/10.1016/S1042-9573(03)00028-7

- 1998. "Bank Holding Company Capital Ratios and Shareholder Payouts." Current Issues in Economics and Finance, vol. 4, no. 9. Available at https://doi.org/10.2139/ssrn.997395

Jensen, Michael. 1986. "Agency Costs of Free Cash Flow, Corporate Finance, and Takeovers." Papers and Proceedings of the Ninety-Eighth Annual Meeting of the American Economic Association, vol. 76, no. 2, pp. 323-329.

Jensen, Michael, and William H. Meckling. 1976. "Theory of the Firm: Managerial Behavior, Agency Costs, and Ownership Structure.” Journal of Financial Economics, vol. 3, pp. 305-360. https://doi.org/10.1016/0304405X(76)90026-X

Kohn, Donald, and Nellie Liang. 2019. "Understanding the Effects of the U.S. Stress Tests." Prepared for the Federal Reserve System Conference, "Stress Testing: A Discussion and Review," Boston, MA, July 9.

Laderman, Elizabeth. 1995. "Bank Stock Repurchases." Federal Reserve Bank of San Francisco, Weekly Letter, vol. 94-43.

Liang, Nellie. 2020. "Banks Should Suspend Share Repurchases for Longer." Brookings Up Front, April 8.

Marsh, W. Blake. 2022. "Supervisory Stringency, Payout Restrictions, and Bank Equity Prices." Federal Reserve Bank of Kansas City, Research Working Paper no. 22-01, January. Available at https://doi.org/10.18651/RWP2022-01 
Sengupta, Rajdeep, and Adam Byrdak. 2021. "Bank Profitability Rebounds despite Compressed Interest Margins." Federal Reserve Bank of Kansas City, Economic Bulletin, November 17.

Vermaelen, Todd. 1984. "Repurchase Tender Offers, Signaling, and Managerial Incentives." Journal of Financial and Quantitative Analysis, vol. 19, no. 2, pp. 163-181. Available at https://doi.org/10.2307/2330896

. 1981. "Common Stock Repurchases and Market Signaling." Journal of Financial Economics, vol. 9, no, 2, pp. 139-183. Available at https://doi. org/10.1016/0304-405X(81)90011-8 